\title{
Immune and production responses of dairy cows to postruminal supplementation with phytonutrients
}

\author{
J. Oh, ${ }^{*}$ A. N. Hristov, ${ }^{* 1}$ C. Lee, ${ }^{*}$ T. Cassidy, ${ }^{*}$ K. Heyler, ${ }^{*}$ G. A. Varga, ${ }^{*}$ J. Pate, ${ }^{*}$ S. Walusimbi, ${ }^{*}$ E. Brzezicka, ${ }^{*}$ \\ K. Toyokawa,* J. Werner,† S. S. Donkin,‡ R. Elias,§ S. Dowd,\# and D. Bravoll \\ *Department of Animal Science, and \\ †Animal Resource Program, The Pennsylvania State University, University Park 16802 \\ fDepartment of Animal Sciences, Purdue University, West Lafayette, IN 47906 \\ §Department of Food Science, The Pennsylvania State University, University Park 16802 \\ \#MR DNA (Molecular Research), Shallowater, TX 79363 \\ IIPancosma S.A., 1218 Geneva, Switzerland
}

\section{ABSTRACT}

This study investigated the effect of phytonutrients (PN) supplied postruminally on nutrient utilization, gut microbial ecology, immune response, and productivity of lactating dairy cows. Eight ruminally cannulated Holstein cows were used in a replicated $4 \times 4$ Latin square. Experimental periods lasted 23 d, including 14-d washout and 9-d treatment periods. Treatments were control (no PN) and daily doses of $2 \mathrm{~g} / \mathrm{cow}$ of either curcuma oleoresin (curcumin), garlic extract (garlic), or capsicum oleoresin (capsicum). Phytonutrients were pulse-dosed into the abomasum of the cows, through the rumen cannula, $2 \mathrm{~h}$ after feeding during the last 9 $\mathrm{d}$ of each experimental period. Dry matter intake was not affected by PN, although it tended to be lower for the garlic treatment compared with the control. Milk yield was decreased $(2.2 \mathrm{~kg} / \mathrm{d})$ by capsicum treatment compared with the control. Feed efficiency, milk composition, milk fat and protein yields, milk $\mathrm{N}$ efficiency, and $4.0 \%$ fat-corrected milk yield were not affected by treatment. Rumen fermentation variables, apparent total-tract digestibility of nutrients, $\mathrm{N}$ excretion with feces and urine, and diversity of fecal bacteria were also not affected by treatment. Phytonutrients had no effect on blood chemistry, but the relative proportion of lymphocytes was increased by the capsicum treatment compared with the control. All PN increased the proportion of total $\mathrm{CD} 4^{+}$cells and total $\mathrm{CD} 4^{+}$cells that co-expressed the activation status signal and CD25 in blood. The percentage of peripheral blood mononuclear cells (PBMC) that proliferated in response to concanavalin $\mathrm{A}$ and viability of $\mathrm{PBMC}$ were not affected by treatment. Cytokine production by PBMC was not different between control and PN. Expression of mRNA

Received May 31, 2013.

Accepted August 31, 2013.

${ }^{1}$ Corresponding author: anh13@psu.edu in liver for key enzymes in gluconeogenesis, fatty acid oxidation, and response to reactive oxygen species were not affected by treatment. No difference was observed due to treatment in the oxygen radical absorbance capacity of blood plasma but, compared with the control, garlic treatment increased 8-isoprostane levels. Overall, the PN used in this study had subtle or no effects on blood cells and blood chemistry, nutrient digestibility, and fecal bacterial diversity, but appeared to have an immune-stimulatory effect by activating and inducing the expansion of CD4 cells in dairy cows. Capsicum treatment decreased milk yield, but this and other effects observed in this study should be interpreted with caution because of the short duration of treatment.

Key words: capsicum, curcumin, garlic, dairy cow

\section{INTRODUCTION}

Many plants produce secondary metabolites that may be useful as feed additives because of their biologically active constituents (Wallace, 2004). Plant-derived bioactive compounds, also referred to as phytonutrients (PN) or phytobiotics, such as phenolic compounds, essential oils, and saponins have been shown to express antimicrobial activities (Cowan, 1999; Bakkali et al., 2008) and have been investigated as alternatives to rumen modifiers, such as ionophoric antibiotics, in animal nutrition (Greathead, 2003; Rochfort et al., 2008). Phytonutrients have also been studied as inhibitors of pathogens having an effect on animal health and productivity (Panda et al., 2006; Jouany and Morgavi, 2007; Giannenas and Kyriazakis, 2009).

Natural products originating from plants have been used in traditional medicine and as feed supplements to livestock diets for centuries. Antimicrobial activities, immune enhancement, and stress reduction are among the beneficial characteristics of these preparations (Wang et al., 1998). Garlic (Allium sativum) and garlic oil, for example, have a wide spectrum of activities from anti- 
microbial, antioxidant, and anticarcinogenic properties to beneficial effects on the cardiovascular and immune systems (Lang et al., 2004; Mirunalini et al., 2010). The antimicrobial properties of $\mathrm{PN}$, demonstrated in monogastric farm species (Youn and Noh, 2001; Ando et al., 2003; Youn et al., 2004; Michiels et al., 2005, 2007), can also be advantageous in suppressing intestinal protozoa and pathogenic bacteria in cattle. Other effects such as immune stimulation, again primarily through inhibition of intestinal parasites (Applegate, 2009), and prebiotic effects have been reported for PN in pigs and poultry (Guo et al., 2004a,b; Maass et al., 2005; Applegate, 2009).

Some PN (particularly phenols) are known to be resistant to microbial degradation in the rumen and could reach the small intestine in a biologically active form. Franz et al. (2010), for example, reported resistance (up to $60 \%$ recovery) of phenolic compounds, such as carvacrol, to microbial degradation in a continuous culture fermentor study. It is possible that these escape rates of phenolic compounds occur in vivo because the rumen is a dynamic system and the passage rate of the liquid phase of ruminal contents can be as high as $20 \% / \mathrm{h}$ (Hristov et al., 2003). Thus, ruminal fluid and any compound associated with it may have a short residence time in the rumen (around $5 \mathrm{~h}$ ) and a high probability of reaching the intestine of the host animal. Once PN reach the absorptive sites in the small intestine, they can be rapidly absorbed (as shown recently for essential oil terpenes from caraway, Carum carvi, and oregano, Origanum vulgare; Lejonklev et al., 2013) and have various physiological effects. Thus, if PN bypass the rumen, they could exhibit the same activities in the lower part of the ruminant digestive tract as previously described in monogastric animals. Improvements in digestibility, of the mucosal and antioxidant status, and immune response could lead to improved animal health, milk production, and feed efficiency in dairy cattle.

Based on evidence in monogastric species, we hypothesized that PN could have immune-stimulating and other beneficial effects in dairy cows. The specific objectives of the study were to investigate postruminal physiological effects of PN in relation to nutrient utilization, gut microbial ecology, immune response, and productivity of lactating dairy cows.

\section{MATERIALS AND METHODS}

\section{Animals and Treatments}

This experiment and all procedures were reviewed and approved by The Pennsylvania State University Animal Care and Use Committee (IACUC protocol no.
35632). Animals were cared for according to the guidelines of the committee.

The design of the experiment was a replicated $4 \times$ 4 Latin square with 1 multiparous and 7 primiparous Holstein cows averaging $533 \pm 75.3 \mathrm{~kg}$ of BW, $175 \pm$ $19.8 \mathrm{DIM}$, and $30.3 \pm 8.01 \mathrm{~kg} / \mathrm{d}$ of milk yield at the beginning of the trial. All cows were fitted with soft plastic rumen cannula (10-cm internal diameter; Bar Diamond Inc., Parma, ID). Experimental periods were $23 \mathrm{~d}$, including 14-d washout and 9-d treatment periods. Treatments were control $(99.9 \%$ ethanol dissolved in distilled water, see below, without $\mathrm{PN}$ ) and $3 \mathrm{PN}$ (Pancosma S.A., Geneva, Switzerland): a daily pulse dose of $2 \mathrm{~g} /$ cow of curcuma oleoresin (curcumin; from Curcuma longs L., containing 95\% curcumin), a daily pulse dose of $2 \mathrm{~g} /$ cow of garlic extract (garlic; containing by weight, $60 \%$ polysorbate 80 and $40 \%$ organosulfur compounds), or a daily pulse dose of $2 \mathrm{~g} / \mathrm{cow}$ of capsicum oleoresin (capsicum; from Capsicum frutescens L. and Capsicum anum L. var. concoides, containing $6 \%$ capsaicin). Phytonutrients were dissolved in $99.9 \%$ ethanol (2 $\mathrm{g}$ of PN in $40 \mathrm{~mL}$ of ethanol) and further diluted with $250 \mathrm{~mL}$ of distilled water. Solutions were pulse-dosed into the abomasum of the cows through the rumen cannula, $2 \mathrm{~h}$ after feeding during the last $9 \mathrm{~d}$ of each experimental period (i.e., the treatment period) using a $500-\mathrm{mL}$ plastic bottle attached to a $155-\mathrm{cm}-$ long polyvinyl tube (10-mm internal diameter). The infusion tube was flushed with an additional $500 \mathrm{~mL}$ of distilled water following the delivery of the treatment solutions. The relatively short treatment period was necessary to reduce, as much as possible, stress to the cows caused by the invasive abomasal infusion procedure. Cows were housed in a tiestall barn, were fed once daily at approximately $0800 \mathrm{~h}$, and had free access to fresh water. The basal diet (Table 1) was fed ad libitum as a TMR to achieve approximately 5 to $10 \%$ refusals. Feed was pushed up 3 to 5 times daily. Cows were milked twice daily at 0500 and $1700 \mathrm{~h}$ and treated with recombinant bST (Posilac; Elanco Co., Greenfield, IN; $500 \mathrm{mg}$, i.m.) at 14-d intervals. Although not analyzed, we assumed that, because of the experimental design of the trial (i.e., Latin square), the bST treatment did not affect the experimental results in this study.

\section{Sampling and Analyses}

Feed intake was measured daily, TMR samples were collected twice weekly, and individual feed ingredients were sampled once weekly. Composite samples of the TMR, forages, and concentrates were stored frozen, oven-dried for $48 \mathrm{~h}$ at $65^{\circ} \mathrm{C}$ (forced-air oven), and ground in a Wiley mill (A. H. Thomas Co., Philadelphia, PA) through a 1-mm screen before being analyzed for CP (N 
Table 1. Ingredient and chemical composition (\% of DM unless otherwise indicated) of the basal diet fed during the trial

\begin{tabular}{|c|c|}
\hline Item & $\%$ of $\operatorname{diet} \mathrm{DM}$ \\
\hline \multicolumn{2}{|l|}{ Ingredient } \\
\hline Corn silage ${ }^{1}$ & 39.7 \\
\hline Alfalfa haylage ${ }^{2}$ & 16.7 \\
\hline Grass hay ${ }^{3}$ & 5.8 \\
\hline Bakery byproduct meal $^{4}$ & 7.4 \\
\hline SoyPLUS ${ }^{5}$ & 6.0 \\
\hline Corn grain, ground & 5.7 \\
\hline Soybean seeds, whole heated & 5.5 \\
\hline Canola meal & 5.0 \\
\hline Sugar blend ${ }^{6}$ & 4.2 \\
\hline Vitamin and mineral premix ${ }^{7}$ & 2.9 \\
\hline Cottonseed, hulls & 1.1 \\
\hline \multicolumn{2}{|l|}{ Composition $^{8}$} \\
\hline $\mathrm{CP}$ & 15.7 \\
\hline $\mathrm{NDF}$ & 29.3 \\
\hline $\mathrm{ADF}$ & 20.4 \\
\hline $\mathrm{NE}_{\mathrm{t}}, \mathrm{Mcal} / \mathrm{kg}$ & 1.56 \\
\hline $\mathrm{NFC}$ & 46.0 \\
\hline Ether extract & 4.1 \\
\hline $\mathrm{Ca}$ & 0.98 \\
\hline $\mathrm{P}$ & 0.36 \\
\hline Average $\mathrm{NE}_{\mathrm{L}}$ balance, ${ }^{9} \mathrm{Mcal} / \mathrm{d}$ & $(-2.4,-2.1,-3.0,-0.5)$ \\
\hline Average MP balance, ${ }^{9} \mathrm{~g} / \mathrm{d}$ & $(-264,-255,-322,-183)$ \\
\hline
\end{tabular}

${ }^{1}$ Corn silage was $42.9 \% \mathrm{DM}$ and contained (DM basis): $7.6 \% \mathrm{CP}$ and $35.5 \% \mathrm{NDF}$.

${ }^{2}$ Alfalfa haylage was $45.4 \% \mathrm{DM}$ and contained (DM basis): $19.5 \% \mathrm{CP}$ and $43.0 \%$ NDF.

${ }^{3}$ Grass hay contained (DM basis): $6.6 \% \mathrm{CP}$ and $66.0 \%$ NDF.

${ }^{4}$ Bakery byproduct meal (Bakery Feeds Inc., Honey Brook, PA).

${ }^{5}$ SoyPLUS (West Central, Ralston, IA); contained $45.3 \%$ CP.

${ }^{6}$ Molasses (Westway Feed Products, Tomball, TX).

${ }^{7}$ The premix contained (\%, as-is basis) trace mineral mix (Cargill Animal Nutrition, Cargill Inc., Roaring Spring, PA), 0.86; $\mathrm{MgO}(56 \%$ $\mathrm{Mg}$ ), 8.0; $\mathrm{NaCl}, 6.4$; vitamin ADE premix (Cargill Animal Nutrition, Cargill Inc.), 0.48; limestone, 37.2; selenium premix (Cargill Animal Nutrition, Cargill Inc.), 0.07; and dry corn distillers grains with solubles, 46.7. Ca, 14.1\%; P, 0.39\%; Mg, 4.59\%; K, 0.44\%; S, 0.39\%; Se, $6.91 \mathrm{mg} / \mathrm{kg} ; \mathrm{Cu}, 362 \mathrm{mg} / \mathrm{kg}$; Zn, 1,085 mg/kg; Fe, $186 \mathrm{mg} / \mathrm{kg}$, vitamin A, 276,717 IU/kg; vitamin D, 75,000 IU/kg; and vitamin E, 1,983 IU/ $\mathrm{kg}$.

${ }^{8}$ Analyzed (or estimated; $\mathrm{NE}_{\mathrm{L}}, \mathrm{NFC}$ ) by Cumberland Valley Analytical Services (Maugansville, MD).

${ }^{9}$ Estimated based on NRC (2001) using actual DMI, milk yield, milk composition, and BW of the cows (control, curcumin, garlic, and capsicum diets, respectively).

$\times 6.25), \mathrm{NDF}, \mathrm{ADF}$, ether extract, $\mathrm{Ca}$, and $\mathrm{P}$ by Cumberland Valley Analytical Services using wet chemistry methods and estimated $\mathrm{NFC}$ and $\mathrm{NE}_{\mathrm{L}}$ (Maugansville, MD; analytical methods are available at http://www. foragelab.com/Resources/Lab-Procedures/; accessed April 30, 2013). Total mixed ration and fecal samples were ashed for $4 \mathrm{~h}$ at $600^{\circ} \mathrm{C}$ for analysis of OM. Samples of the TMR were also analyzed for indigestible NDF (iNDF; see below).

Milk production of the cows was recorded daily, and milk yield, DMI, and estimated feed efficiency data for the last $6 \mathrm{~d}$ of each treatment period (i.e., after $3 \mathrm{~d}$ of $\mathrm{PN}$ administration) were used in the statistical analy- sis. Dry matter intake was calculated by adjusting daily as-fed feed intake to DM content (measured for $48 \mathrm{~h}$ at $65^{\circ} \mathrm{C}$ ) of the weekly TMR and refusals composited samples. Samples for milk composition were collected on the last $2 \mathrm{~d}$ of each treatment period, from a.m. and p.m. milkings, preserved with 2-bromo-2-nitropropane-1,3 diol, and submitted to Dairy One laboratory (Pennsylvania DHIA, University Park) for analysis of milk fat, true protein, lactose, and MUN using infrared spectroscopy (MilkoScan 4000; Foss Electric, Hillerød, Denmark). Milk composition data of the 2 sampling days were averaged and the average values used in the statistical analysis. Averaged milk yield and DMI for the 6 data collection days and averaged milk composition data were used to calculate milk fat, protein, lactose, $4.0 \% \mathrm{FCM}$, and $\mathrm{NE}_{\mathrm{L}}$ yield and efficiency.

Rumen samples were collected once during each experimental period (on d 7 of the treatment period), 3 $\mathrm{h}$ after feeding. Whole ruminal contents were sampled, processed, and analyzed for $\mathrm{pH}$, VFA, and ammonia concentration as described elsewhere (Hristov et al., 2013).

Spot fecal and urine samples were collected by stimulating defecation or from the rectum and by massaging the vulva, respectively, at 0900,1500 , and $2100 \mathrm{~h}$ on d 6 and at 0300, 0600, 1200, 1800, and $0000 \mathrm{~h}$ on d 7 of each treatment period. Approximately 300-g wet fecal and 500-mL urine samples were collected per sampling. Aliquots of the fecal samples (approximately 50 g per sampling, wet basis) were composited, per cow and period, and stored frozen in $-80^{\circ} \mathrm{C}$ for bacterial population analysis using tag-encoded FLX amplicon pyrosequencing and Gray28F 5'GAGTTTGATCNTGGCTCAG and Gray519R 5'GTNTTACNGCGGCKGCTG primers (Dowd et al., 2008a,b). For details on these analyses, see Hristov et al. (2013). The remaining fecal sample was oven-dried at $65^{\circ} \mathrm{C}$ in a forced-air oven for $48 \mathrm{~h}$. After drying, samples were ground through a 1-mm sieve (Wiley mill), composited per cow and period, and analyzed for OM and amylase-treated NDF (aNDF) and ADF (Ankom A200 fiber analyzer; Ankom Technology, Macedon, NY, and Van Soest et al., 1991). Heat-stable amylase (Ankom Technology) and sodium sulfite (Fisher Scientific, Waltham, MA) were used in the aNDF procedure. Fecal samples were pulverized at $30 \mathrm{~Hz} / \mathrm{s}$ for $2 \mathrm{~min}$ in a Mixer Mill MM 200 (Retsch $\mathrm{GmbH}$, Haan, Germany) and analyzed for $\mathrm{CP}(\mathrm{N} \times$ 6.25) on a Costech ECS $4010 \mathrm{C} / \mathrm{N} / \mathrm{S}$ elemental analyzer (Costech Analytical Technologies Inc., Valencia, CA). Apparent total-tract digestibility of nutrients was estimated using iNDF as an intrinsic digestibility marker (Schneider and Flatt, 1975). Fecal and TMR samples were analyzed for iNDF according to Huhtanen et al. (1994), with the exception that 25- $\mu$ m pore size Ankom 
filter bags (Ankom Technology) were used for the rumen incubation. Urine samples were acidified $(\mathrm{pH}<3)$ using $2 M \mathrm{H}_{2} \mathrm{SO}_{4}$ ( $\mathrm{pH}$ was verified using litmus paper), diluted 1:10 with distilled water, composited per cow and period, and stored frozen at $-20^{\circ} \mathrm{C}$. Urine samples were analyzed for $\mathrm{N}$ (as for feces), urea-N (Stanbio Urea Nitrogen Kit 580; Stanbio Laboratory Inc., San Antonio, TX), and creatinine (Stanbio Creatinine Kit 0400; Stanbio Laboratory Inc.). Daily volume of excreted urine was estimated based on urinary creatinine concentration, assuming a creatinine excretion rate of $29 \mathrm{mg} / \mathrm{kg}$ of BW (determined based on total urine collection samples from Hristov et al., 2011). Estimated urine output was used to calculate daily total $\mathrm{N}$ and urinary urea- $\mathrm{N}$ excretions.

Blood samples were collected from the coccygeal tail vein or artery at 2 and $4 \mathrm{~h}$ after $\mathrm{PN}$ administration on d 6 and 7 of each treatment period. Samples (approximately $10 \mathrm{~mL}$ ) were collected into Vacutainer tubes containing EDTA (BD Biosciences, Franklin Lakes, $\mathrm{NJ})$, kept refrigerated $\left(4^{\circ} \mathrm{C}\right)$, and analyzed the same day for hematology analyses. The analyses included red blood cell count, hemoglobin, hematocrit, red blood cell parameters (mean corpuscular volume, mean corpuscular hemoglobin, mean corpuscular hemoglobin concentration, red cell distribution width, platelet count, and mean platelet volume), and total white blood cell count, including total count for neutrophils, eosinophils, lymphocytes, monocytes, and basophils using an automated hematology analyzer (HemaVet, Drew Scientific, Oxford, CT). A separate set of blood samples was collected into Vacutainer tubes containing silica clot activator (SST tube, BD Biosciences); blood serum was separated (after clotting) through centrifugation at $3,000 \times g$ and room temperature for $15 \mathrm{~min}$, and analyzed for albumin, alkaline phosphatase, alanine aminotransferase, amylase, BUN, Ca, cholesterol, creatinine, globulin, glucose, $\mathrm{P}, \mathrm{K}, \mathrm{Na}$, total bilirubin, total protein (Idexx VetTest and VetLyte Chemistry and Electrolyte Analyzers, Idexx Laboratories Inc., Westbrook, ME). A third set of blood samples was collected into Vacutainer tubes containing EDTA (BD Biosciences). Plasma was obtained as described elsewhere (Tekippe et al., 2011), composited per cow, period, and sampling time point, and stored frozen at $-80^{\circ} \mathrm{C}$. Plasma was analyzed for the oxidative stress markers 8-isoprostane and oxygen radical absorbance capacity (ORAC), as described elsewhere (Ju et al., 2009 and Cao and Prior, 1999, respectively).

Whole blood (approximately $250 \mathrm{~mL}$ ) was collected via jugular venipuncture before feeding from 4 cows on $\mathrm{d} 8$ and from the other 4 cows on d 9 of each treatment period for immune response analyses. Peripheral blood mononuclear cells (PBMC) were isolated fol- lowing procedures described by Ndiaye et al. (2008) for analysis of proliferation, T-cell phenotypes, and cytokine production. For the proliferation assay, 25 $\times 10^{6}$ PBMC were incubated with carboxyfluorescein succinimidyl ester $(1.75 \mu M$; Sigma Chemical Co., St. Louis, MO) in serum-free AIM-V medium (Invitrogen, Grand Island, NY) at $37^{\circ} \mathrm{C}$ for $15 \mathrm{~min}$ and then at room temperature for another $10 \mathrm{~min}$. The cells were diluted 5 -fold with medium containing $10 \%$ fetal calf serum (Invitrogen) and washed 3 times at $300 \times g$ for $10 \mathrm{~min}$. Labeled PBMC were cultured and treated with either concanavalin A (Sigma Chemical Co.) or PBS (as a control) in 96-well plates for $72 \mathrm{~h}$. Proliferation was determined by flow cytometery (GuavaEasyCyte Plus, Millipore, Billerica, MA).

To determine the effect of $\mathrm{PN}$ on T-lymphocyte phenotypes, $1 \times 10^{6} \mathrm{PBMC}$ were directly labeled with Fluor-conjugated primary antibodies against T-lymphocyte surface antigens following a protocol described by Poole and Pate (2012). The antibodies used were against cluster of differentiation (CD)4 (MCA1653F; AbD Serotec, Raleigh, NC) and CD25a (MCA2430PE; AbD Serotec), CD8 $\alpha$ (MCA837F; AbD Serotec) and CD8 $\beta$ (MCA1654PE; AbD Serotec), CD8 $\alpha$, ACT2 [an activation marker, ACT2 (CACT26A; VMRD, Pullman, WA], $\delta$ T-cell receptor ( $\delta$ TCR; GB21A, VMRD) and CD8a, $\delta \mathrm{TCR}$, and WC1 (MCA838F; AbD Serotec). The $\delta$ TCR antibody was conjugated to phycoerythrin using the Zenon R-phycoerythrin mouse IgG2b labeling kit (Z25255; Invitrogen). Each sample was labeled in duplicate with the following combinations of antibodies: CD 4 and $\mathrm{CD} 25 \alpha, \mathrm{CD} 8 \alpha$ and $\mathrm{CD} 8 \beta, \mathrm{CD} 8 \alpha$ and ACT2, $\delta \mathrm{TCR}$ and $\mathrm{CD} 8 \alpha$, and $\delta \mathrm{TCR}$ and $\mathrm{WC} 1$. Control antibodies used were IgG2b negative control (MCA691PE; AbD Serotec), IgG2a negative control (MCA929F; AbD Serotec), and IgG1 negative control (MCA928PE and MCA928F; AbD Serotec). The proportion of stained cells was determined by flow cytometry (GuavaEasyCyte Plus, Millipore).

Production of the proinflammatory cytokines tumor necrosis factor (TNF), IFN $\gamma$, and IL6 was measured in the medium of cultured PBMC by ELISA (ELISA plates for all cytokines were purchased from Thermo Fisher Scientific, Waltham, MA). The PBMC were cultured for $48 \mathrm{~h}$ in the presence or absence of LPS at $1 \mu \mathrm{g} / \mathrm{mL}$.

Liver tissue samples were collected by blind percutaneous needle biopsy as described previously (Greenfield et al., 2000) from 4 cows on d 8 and from the other 4 cows on d 9 of each treatment period, $4 \mathrm{~h}$ after PN administration. Samples were rinsed once with ice-cold saline and an aliquot (500 to 1,000 mg) was transferred to a tube containing Trizol solution (Invitrogen) for RNA isolation and immediately frozen at $-80^{\circ} \mathrm{C}$. Liver 
tissue was analyzed for key transcripts that represent control points for gluconeogenesis (phosphoenolpyruvate carboxykinase-C, glucose 6-phosphatase, and pyruvate carboxylase), fatty acid oxidation (carnitine palmitoyltransferase $1 \mathrm{~A}$ ), response to reactive oxygen species (catalase and glutathione peroxidase), and protease inhibitors ( $\alpha$-2-macroglobulin). Abundance of mRNA transcripts was quantified using real-time PCR, brilliant SYBR Green reagent and QPCR Master Mix (Stratagene, Cedar Creek, TX), and the following primers: PC, CCACGAGTTCTCCAACACCT (forward), TTCTCCTCCAGCTCCTCGTA (reverse); phosphoenolpyruvate carboxykinase-C, AACCTGGCCATGATGAACCCTACT (forward), ACTCCTTGCCCTTCCAGGAAATGA (reverse); bovine 18S, ACCCATTCGAACGTCTGCCCTATT (forward), TCCTTGGATTGTGGTAGCCGTTTCT (reverse), carnitine palmitoyltransferase 1A TCCAGCTGGCTCATTACAAGGACA (forward), TCTCAGACGCGATCCTGAACAACT (reverse), catalase ATCTCACTCAGGTGCGGACTTTCT (forward), AGGTGTGAACACCATGCTCTGCTT (reverse), and glutathione peroxidase AAAGTGCGAGGTGAATGGCGAGAA (forward), ACAGCAGGGTTTCAATGTCAGGCT (reverse). The no-reverse-transcriptase control was formed by combining an equivalent quantity of purified RNA for each sample, and water served as the no-template control. A cDNA pool was formed from an equivalent quantity of cDNA from each sample diluted with nuclease-free water in a 1:4 dilution series to generate a standard curve. The relative abundance of each mRNA was determined using dilutions of the cDNA pool as a reference. The PCR reactions were as follows: 1 cycle at $95^{\circ} \mathrm{C}$ for $10 \mathrm{~min} ; 40$ cycles of $95^{\circ} \mathrm{C}$ for $30 \mathrm{~s}$, $55^{\circ} \mathrm{C}$ for $1 \mathrm{~min}$, and $72^{\circ} \mathrm{C}$ for $30 \mathrm{~s}$; and 1 cycle of $95^{\circ} \mathrm{C}$ for $1 \mathrm{~min}, 55^{\circ} \mathrm{C}$ for $30 \mathrm{~s}$, and $95^{\circ} \mathrm{C}$ for $30 \mathrm{~s}$. Reaction efficiencies were between 90 and $110 \%$, and all samples, standards, and controls were analyzed in triplicate and values normalized to $18 \mathrm{~S}$ mRNA abundance within each sample.

\section{Statistical Analysis}

All data were analyzed using the MIXED procedure of SAS (2003; SAS Institute Inc., Cary, NC) by ANOVA Latin square. The model included square, cow within square, period, and treatment, with the error term assumed to be normally distributed with mean $=0$ and constant variance. Square and cow within square were random effects and all others were fixed. Feed intake and milk yield data were analyzed as repeated measures assuming an autoregressive first-order covariance structure. The model was similar to that described above but contained time of sampling effect and treatment $x$ time interaction. When the main effect of treatment was significant, means were separated by pairwise $t$-test (pdiff option of PROC MIXED). Statistical differences were declared at $P \leq 0.05$. Differences between treatments at $0.05<P \leq 0.10$ were considered as a trend toward significance.

\section{RESULTS}

The basal diet fed in this trial (Table 1) was identical to a diet fed in a concurrent trial (the adequate-MP diet in Lee et al., 2012) and was formulated to meet the $\mathrm{NE}_{\mathrm{L}}$ and $\mathrm{MP}$ requirements of the cows. Due to lowerthan-expected feed intake, however, the diet supplied inadequate amounts of $\mathrm{NE}_{\mathrm{L}}$ and $\mathrm{MP}$ for all treatments; $\mathrm{NE}_{\mathrm{L}}$ deficiency was from 1 (capsicum treatment) to $8 \%$ (garlic treatment) and MP deficiency was from 7 (capsicum treatment) to 13\% (garlic treatment; according to NRC, 2001). Body weight of the cows was not affected by treatment (average of $564 \mathrm{~kg}, \mathrm{SEM}=26.1$; $P=0.66$ ), but as a result of nutrient supply deficiencies, all cows lost BW during the trial; BW loss was on average $22 \pm 3.13 \mathrm{~kg}$ (approximately $240 \mathrm{~g} / \mathrm{d}$ ).

Dry matter intake was similar between the control, curcumin, and capsicum treatments, but tended to be lower $(P=0.09$; by about $1.3 \mathrm{~kg} / \mathrm{d}$ compared with the control) for the garlic treatment compared with all other treatments (Table 2). We detected a trend for effect of time (i.e., day of PN treatment; $P=0.09$ ) on DMI but no time $\times$ treatment interaction $(P=0.93)$. Intake of DM varied from day to day (20.0 to $21.5 \mathrm{~kg} / \mathrm{d}$ ) with no trend for a steady increase or decrease with the initiation of PN administration (data not shown in tables). Milk yield was decreased (by $2.2 \mathrm{~kg} / \mathrm{d} ; P=0.05$ ) by the capsicum treatment compared with the control. We observed no time or time $\times$ treatment effect for milk yield ( $P=0.34$ and 0.98 , respectively). Because of the lower DMI, feed efficiency was numerically greater $(P=$ 0.15 ) by about $4.5 \%$ for the garlic treatment compared with the control but was about $6 \%$ lower for capsicum (again, compared with the control). Phytonutrients had no effects on milk composition, milk fat and protein yields, milk $\mathrm{N}$ efficiency, 4.0\% FCM yield, or the efficiency of feed $\mathrm{NE}_{\mathrm{L}}$ use.

Rumen fermentation variables were not affected $(P>0.29$; data not shown in tables) by treatment. Rumen $\mathrm{pH}$ (overall mean followed by SEM; 6.10, 0.043), ammonia concentration (9.0 $\mathrm{m} M, 0.76)$, total VFA (107 m M, 3.4), individual VFA concentrations, and acetate:propionate ratio $(2.6,0.14)$ were within normal ranges and similar between control and PN treatments. Apparent total-tract digestibility of DM (\%, overall mean followed by SEM; $64.3,0.67)$, OM $(65.6,0.64), \mathrm{CP}(61.7,1.24)$, aNDF $(37.2,0.85)$, and 
Table 2. Effect of phytonutrients on milk yield and composition in dairy cows (LSM)

\begin{tabular}{|c|c|c|c|c|c|c|}
\hline \multirow[b]{2}{*}{ Item } & \multicolumn{4}{|c|}{ Treatment $^{1}$} & \multirow[b]{2}{*}{$\mathrm{SEM}^{2}$} & \multirow[b]{2}{*}{$P$-value ${ }^{3}$} \\
\hline & Control & Curcumin & Garlic & Capsicum & & \\
\hline DMI, $\mathrm{kg} / \mathrm{d}$ & 21.2 & 21.2 & 19.9 & 21.3 & 1.89 & $0.09^{4}$ \\
\hline Milk yield, $\mathrm{kg} / \mathrm{d}$ & $37.4^{\mathrm{a}}$ & $36.4^{\mathrm{ab}}$ & $35.8^{\mathrm{ab}}$ & $35.2^{\mathrm{b}}$ & 2.82 & 0.05 \\
\hline Milk/DMI, $\mathrm{kg} / \mathrm{kg}$ & 1.79 & 1.80 & 1.87 & 1.69 & 0.100 & 0.15 \\
\hline Milk fat, $\%$ & 3.69 & 3.77 & 3.64 & 3.56 & 0.210 & 0.58 \\
\hline Milk fat yield, $\mathrm{kg} / \mathrm{d}$ & 1.37 & 1.39 & 1.29 & 1.26 & 0.121 & 0.27 \\
\hline $4.0 \% \mathrm{FCM}, \mathrm{kg} / \mathrm{d}$ & 35.3 & 35.6 & 33.5 & 33.0 & 2.70 & 0.21 \\
\hline Milk true protein, $\%$ & 3.18 & 3.25 & 3.24 & 3.24 & 0.079 & 0.59 \\
\hline Milk true protein yield, $\mathrm{kg} / \mathrm{d}$ & 1.17 & 1.20 & 1.15 & 1.14 & 0.130 & 0.94 \\
\hline MPN yield, ${ }^{5} \mathrm{~g} / \mathrm{d}$ & 185 & 186 & 182 & 179 & 21.5 & 0.97 \\
\hline MPN efficiency ${ }^{5}$ & 35.4 & 36.8 & 37.3 & 33.6 & 1.75 & 0.56 \\
\hline Milk lactose, $\%$ & 4.84 & 4.90 & 4.88 & 4.93 & 0.061 & 0.32 \\
\hline Milk lactose yield, $\mathrm{kg} / \mathrm{d}$ & 1.80 & 1.81 & 1.72 & 1.73 & 0.117 & 0.41 \\
\hline Milk $\mathrm{NE}_{\mathrm{L}}{ }^{6}{ }^{6} \mathrm{Mcal} / \mathrm{d}$ & 26.5 & 26.5 & 25.5 & 25.0 & 1.99 & 0.88 \\
\hline $\mathrm{NE}_{\mathrm{L}}$ intake, $\mathrm{Mcal} / \mathrm{d}$ & 35.6 & 35.5 & 33.2 & 35.9 & 3.14 & 0.26 \\
\hline $\mathrm{NE}_{\mathrm{L}}$ efficiency $^{7}$ & 74.9 & 76.9 & 78.2 & 69.9 & 3.18 & 0.25 \\
\hline MUN, mg/100 mL & 13.0 & 11.7 & 11.9 & 11.9 & 0.49 & 0.27 \\
\hline $\mathrm{SCC}^{8} \times 10^{3}$ cells $/ \mathrm{mL}$ & 516 & 134 & 432 & 407 & 202.7 & 0.21 \\
\hline
\end{tabular}

${ }^{\mathrm{a}, \mathrm{b}}$ Within a row, means without a common superscript letter differ $(P<0.05)$.

${ }^{1}$ Control = abomasal administration of $290 \mathrm{~mL} /$ cow per day of ethanol solution; curcumin = abomasal administration of $2 \mathrm{~g} / \mathrm{cow}$ per day of curcuma oleoresin dissolved in $290 \mathrm{~mL}$ of ethanol solution; garlic = abomasal administration of $2 \mathrm{~g} / \mathrm{d}$ of garlic extract dissolved in $290 \mathrm{~mL}$ of ethanol solution; capsicum = abomasal administration of $2 \mathrm{~g} / \mathrm{d}$ of capsicum oleoresin dissolved in $290 \mathrm{~mL}$ of ethanol solution.

${ }^{2}$ Highest SEM shown; $\mathrm{n}=232$ to 246 for milk yield, DMI, and milk/DMI, $\mathrm{n}=29$ to 32 for all other variables (n represents number of observations used in the statistical analysis).

${ }^{3}$ Main effect of treatment.

${ }^{4}$ Garlic compared with all other treatments, $P<0.04$.

${ }^{5} \mathrm{MPN}=$ milk protein $\mathrm{N}$ (milk true protein $\left./ 6.38\right) ; \mathrm{MPN}$ efficiency $=(\mathrm{MPN}$ yield $/ \mathrm{N}$ intake $) \times 100$.

${ }^{6} \mathrm{Milk} \mathrm{NE}_{\mathrm{L}}(\mathrm{Mcal} / \mathrm{d})=\mathrm{kg}$ of milk $\times(0.0929 \times \%$ fat $+0.0563 \times \%$ true protein $+0.0395 \times \%$ lactose $)(\mathrm{NRC}$, 2001).

${ }^{7}$ Milk NE $/ \mathrm{NE}_{\mathrm{L}}$ intake (Mcal/Mcal).

${ }^{8} \mathrm{SCC}$ data were processed for outlier identification based on an absolute studentized residual value $>2$ (PROC REG of SAS; SAS Institute Inc., Cary, NC).

$\operatorname{ADF}(34.5,0.88)$ were not affected by treatment $(P$ $>0.52$; data not shown in tables). Fecal bacteria were also not affected by treatment (Table 3). The 5 most predominant bacterial genera in fecal mass were Clostridium (on average $10.5 \%$ of the total copies of $16 \mathrm{~S}$ rDNA), Eubacterium (10.2\%), Ruminococcus (9.8\%), Bacteroides (8.4\%), and Oscillospira (8.4\%). Nitrogen intake, nitrogen excretion with feces or urine, urinary urea $\mathrm{N}$ excretion, and total excreta $\mathrm{N}$ did not differ among treatments (Table 4).

Chemical analysis of blood serum showed no differences $(P>0.15$; data not shown in tables $)$ due to treatment. Blood glucose (overall mean followed by SEM; $64.5 \mathrm{mg} / \mathrm{dL}, 3.63)$, BUN (9.6 mg/dL, 0.68), creatinine $(0.76 \mathrm{mg} / \mathrm{dL}, 0.059)$, total protein $(7.15 \mathrm{~g} /$ $\mathrm{dL}, 0.258)$, albumin $(2.83 \mathrm{~g} / \mathrm{dL}, 0.175)$, globulin $(4.37$ $\mathrm{g} / \mathrm{dL}, 0.168)$, alkaline phosphatase (69.7 U/L, 7.76), total bilirubin $(0.25 \mathrm{mg} / \mathrm{dL}, 0.065)$, amylase $(25.0 \mathrm{U} / \mathrm{L}$, 3.28), Ca (10.1 mg/dL, 1.84), P (5.77 mg/dL, 0.358), $\mathrm{Na}, \mathrm{K}$, and $\mathrm{Cl}$ were within the normal ranges for cattle (Bos taurus). Alanine aminotransferase (50.1 U/L, $2.77)$ and cholesterol $(235 \mathrm{mg} / \mathrm{dL}, 17.1)$ concentrations were slightly elevated in all cows, except those in the garlic treatment $(P=0.93$ and 0.21 , respectively), relative to normal ranges for dairy cattle. Blood cell counts were generally not affected by treatment (Table $5)$. Compared with the control, the relative proportion of neutrophils tended to be slightly lower $(P=0.09)$ for cows in the curcumin and capsicum groups and slightly higher for garlic; that of lymphocytes was increased $(P=0.04)$ in the capsicum treatment compared with the control and garlic treatments. Concentration of red blood cells, hematocrit percentage $(P=0.11)$, platelet count, and hemoglobin $(P=0.11)$ concentration did not differ between control and $\mathrm{PN}$ treatments.

With one notable exception, PN had no effects on blood T-cell phenotypes, proliferation, or viability (Table 6). The proportion of total CD $4^{+}$(and $\mathrm{CD} 4^{+} \mathrm{CD} 25^{-}$) cells was greater $(P \leq 0.03)$ in blood samples from cows treated with PN than in the control cows. We also detected numerical trends for increased (2-fold; $P$ $=0.28)$ total $\mathrm{CD}^{+}$that co-expressed the activation status signal CD25 (IL2 receptor) in PN compared with the control. The percentage of PBMC that proliferated 
OH ET AL.

Table 3. Effect of phytonutrients on fecal microbial population (LSM; \% copies) in dairy cows

\begin{tabular}{lcccccc}
\hline & \multicolumn{7}{c}{ Treatment $^{1}$} & & \\
\cline { 2 - 5 } Genus & Control & Curcumin & Garlic & Capsicum & SEM $^{2}$ & $P_{\text {-value }}{ }^{3}$ \\
\hline Clostridium & 10.2 & 10.6 & 10.4 & 10.6 & 0.44 & 0.79 \\
Eubacterium & 10.7 & 9.56 & 9.79 & 10.7 & 0.761 & 0.55 \\
Ruminococcus & 9.62 & 9.40 & 10.5 & 9.74 & 0.569 & 0.21 \\
Bacteroides & 8.55 & 7.89 & 7.88 & 9.31 & 0.726 & 0.44 \\
Oscillospira & 9.62 & 8.17 & 7.88 & 7.75 & 0.743 & 0.19 \\
Odoribacter & 8.31 & 7.09 & 7.97 & 9.00 & 1.198 & 0.68 \\
Fecalibacterium & 7.58 & 9.15 & 7.25 & 7.36 & 1.238 & 0.52 \\
Blautia & 3.19 & 3.67 & 3.69 & 3.43 & 0.331 & 0.67 \\
Alistipes & 3.62 & 2.88 & 2.96 & 3.61 & 0.451 & 0.45 \\
Anaerotruncus & 2.58 & 3.24 & 3.01 & 3.03 & 0.349 & 0.67 \\
Roseburia & 3.04 & 2.85 & 2.96 & 2.73 & 0.276 & 0.86 \\
Sarcina & 1.94 & 2.58 & 2.46 & 2.08 & 0.473 & 0.74 \\
Prevotella & 1.70 & 1.99 & 1.56 & 1.73 & 0.181 & 0.23 \\
Coprococcus & 1.80 & 1.28 & 1.36 & 1.54 & 0.221 & 0.41 \\
Candidate Division TM7 & 1.31 & 1.39 & 1.37 & 1.38 & 0.444 & 1.00 \\
Porphyromonas & 0.94 & 0.84 & 1.01 & 1.15 & 0.140 & 0.55 \\
Bulleidia & 0.78 & 1.01 & 1.10 & 0.79 & 0.199 & 0.62 \\
Anaerovorax & 0.84 & 0.90 & 0.76 & 1.00 & 0.108 & 0.47 \\
Treponema & 0.80 & 0.90 & 0.96 & 0.79 & 0.193 & 0.70 \\
Tannerella & 0.83 & 0.88 & 0.71 & 0.68 & 0.156 & 0.75 \\
\hline
\end{tabular}

${ }^{1}$ Control = abomasal administration of $290 \mathrm{~mL} /$ cow per day of ethanol solution; curcumin = abomasal administration of $2 \mathrm{~g} /$ cow per day of curcuma oleoresin dissolved in $290 \mathrm{~mL}$ of ethanol solution; garlic = abomasal administration of $2 \mathrm{~g} / \mathrm{d}$ of garlic extract dissolved in $290 \mathrm{~mL}$ of ethanol solution; capsicum = abomasal administration of $2 \mathrm{~g} / \mathrm{d}$ of capsicum oleoresin dissolved in $290 \mathrm{~mL}$ of ethanol solution.

${ }^{2} \mathrm{n}=32$ (n represents number of observations used in the statistical analysis).

${ }^{3}$ Main effect of treatment.

(without concanavalin A) increased numerically $(P=$ $0.24)$, with more than twice as many cells proliferating in the PN groups compared with the control group. Viability of PBMC was not affected by treatment. Cytokine production also did not differ between control and PN.

Phytonutrients had no effect on expression of mRNA in liver for key enzymes (Table 7), although we ob- served numerical increases in pyruvate carboxylase (on average $55 \%$ ), glucose 6 -phosphatase $(52 \%)$, and glutathionine peroxidase (45\%) and a numerical decrease in o-2-macroglobulin (40\%) with PN compared with the control group $(P>0.57)$. Phytonutrients did not affect the ORAC of blood plasma, but garlic increased $(P=$ 0.02) 8-isoprostane levels compared with the control (and capsicum; Figure 1).

Table 4. Effect of phytonutrients on fecal and urinary N excretion (LSM) in dairy cows

\begin{tabular}{|c|c|c|c|c|c|c|}
\hline \multirow[b]{2}{*}{ Item } & \multicolumn{4}{|c|}{ Treatment $^{1}$} & \multirow[b]{2}{*}{$\mathrm{SEM}^{2}$} & \multirow[b]{2}{*}{$P$-value ${ }^{3}$} \\
\hline & Control & Curcumin & Garlic & Capsicum & & \\
\hline $\mathrm{N}$ intake, $\mathrm{g} / \mathrm{d}$ & 528 & 526 & 497 & 539 & 48.1 & 0.34 \\
\hline \multicolumn{7}{|l|}{$\mathrm{N}$ excretion, $\mathrm{g} / \mathrm{d}$} \\
\hline Urine N & 148 & 160 & 159 & 153 & 15.0 & 0.85 \\
\hline Urea N & 93.6 & 93.1 & 97.7 & 89.6 & 10.10 & 0.90 \\
\hline Fecal N & 204 & 199 & 186 & 202 & 14.7 & 0.18 \\
\hline Total excreta N & 351 & 359 & 346 & 354 & 25.2 & 0.87 \\
\hline \multicolumn{7}{|c|}{ As proportion of $\mathrm{N}$ intake, $\%$} \\
\hline Urine N & 29.3 & 32.3 & 32.5 & 28.6 & 3.09 & 0.71 \\
\hline Fecal N & 38.8 & 38.3 & 38.4 & 37.6 & 1.24 & 0.89 \\
\hline Total excreta N & 68.0 & 70.6 & 70.9 & 66.2 & 3.64 & 0.76 \\
\hline
\end{tabular}

${ }^{1}$ Control = abomasal administration of $290 \mathrm{~mL} /$ cow per day of ethanol solution; curcumin = abomasal administration of $2 \mathrm{~g} /$ cow per day of curcuma oleoresin dissolved in $290 \mathrm{~mL}$ of ethanol solution; garlic = abomasal administration of $2 \mathrm{~g} / \mathrm{d}$ of garlic extract dissolved in $290 \mathrm{~mL}$ of ethanol solution; capsicum = abomasal administration of $2 \mathrm{~g} / \mathrm{d}$ of capsicum oleoresin dissolved in $290 \mathrm{~mL}$ of ethanol solution.

${ }^{2} \mathrm{n}=32$ (n represents number of observations used in the statistical analysis).

${ }^{3}$ Main effect of treatment. 
Table 5. Effect of phytonutrients on blood cell counts and hemoglobin (LSM) in dairy cows

\begin{tabular}{|c|c|c|c|c|c|c|}
\hline \multirow[b]{2}{*}{ Item } & \multicolumn{4}{|c|}{ Treatment $^{1}$} & \multirow[b]{2}{*}{$\mathrm{SEM}^{2}$} & \multirow[b]{2}{*}{$P$-value ${ }^{3}$} \\
\hline & Control & Curcumin & Garlic & Capsicum & & \\
\hline White blood cell, $10^{3} / \mu \mathrm{L}$ & 9.46 & 9.14 & 9.37 & 9.16 & 0.588 & 0.69 \\
\hline Neutrophils & 5.09 & 4.94 & 5.36 & 4.89 & 0.587 & 0.19 \\
\hline Lymphocytes & 3.73 & 3.67 & 3.43 & 3.72 & 0.284 & 0.19 \\
\hline Monocytes & 0.32 & 0.26 & 0.26 & 0.28 & 0.029 & 0.12 \\
\hline Eosinophils & 0.31 & 0.26 & 0.28 & 0.25 & 0.063 & 0.68 \\
\hline Basophils & 0.03 & 0.02 & 0.03 & 0.02 & 0.007 & 0.33 \\
\hline \multicolumn{7}{|l|}{ As $\%$ of total } \\
\hline Neutrophils & 54.1 & 53.3 & 55.4 & 52.2 & 3.11 & 0.09 \\
\hline Lymphocytes & $39.2^{\mathrm{b}}$ & $40.8^{\mathrm{ab}}$ & $38.6^{\mathrm{b}}$ & $41.8^{\mathrm{a}}$ & 3.33 & 0.04 \\
\hline Monocytes & 3.23 & 2.84 & 2.84 & 3.10 & 0.224 & 0.24 \\
\hline Eosinophils & 3.21 & 2.86 & 2.84 & 2.67 & 0.601 & 0.80 \\
\hline Basophils & 0.26 & 0.26 & 0.30 & 0.21 & 0.063 & 0.56 \\
\hline Red blood cells, $10^{6} / \mu \mathrm{L}$ & 5.91 & 5.86 & 6.01 & 6.01 & 0.186 & $0.22^{4}$ \\
\hline Hematocrit, \% & 26.5 & 25.9 & 26.6 & 26.9 & 0.59 & 0.11 \\
\hline Platelet count, $10^{3} / \mu \mathrm{L}$ & 394 & 396 & 385 & 363 & 33.7 & 0.57 \\
\hline Hemoglobin, g/dL & 9.24 & 9.08 & 9.34 & 9.31 & 0.210 & 0.11 \\
\hline
\end{tabular}

$\overline{\mathrm{a}, \mathrm{b}}$ Within a row, means without a common superscript letter differ $(P<0.05)$.

${ }^{1}$ Control $=$ abomasal administration of $290 \mathrm{~mL} /$ cow per day of ethanol solution; curcumin = abomasal administration of $2 \mathrm{~g} / \mathrm{cow}$ per day of curcuma oleoresin dissolved in $290 \mathrm{~mL}$ of ethanol solution; garlic = abomasal administration of $2 \mathrm{~g} / \mathrm{d}$ of garlic extract dissolved in $290 \mathrm{~mL}$ of ethanol solution; capsicum = abomasal administration of $2 \mathrm{~g} / \mathrm{d}$ of capsicum oleoresin dissolved in $290 \mathrm{~mL}$ of ethanol solution.

${ }^{2} \mathrm{n}=126$ (n represents number of observations used in the statistical analysis).

${ }^{3}$ Main effect of treatment.

${ }^{4}$ Treatment $\times$ time of sampling interaction, $P<0.01$. Phytonutrient means were not different $(P>0.05)$ from the control at both sampling time points.

\section{DISCUSSION}

Various forms of plant extracts, based on some of the active compounds used in the current study, have been investigated as rumen modifiers in dairy cows, having limited or no effects on feed intake and milk production or composition (for example, Yang et al., 2007; Tager and Krause, 2011; Boyd et al., 2012). To our knowledge, however, this is the first study to report production effects of PN supplied postruminally. Cows received PN treatments for a relatively short period, $9 \mathrm{~d}$, to avoid stress from the abomasal infusion procedure. Production and feed intake data were collected following a short adaptation period, which might not have been sufficient to trigger stable feed intake and production responses. The lack of time effect (i.e., days of $\mathrm{PN}$ treatment) on milk production, however, is an indication that, within the $9 \mathrm{~d}$ of treatment, milk production did not change significantly across treatments. As indicated earlier, there also was no clear trend in DMI during the 9-d treatment period, despite the trend for effect of time (no time $\times$ treatment interaction). Thus, within the specific conditions of this trial, the curcumin and capsicum treatments did not affect DMI but numerically decreased milk yield, whereas the garlic treatment tended to decrease both DMI and milk yield. Although the effect of garlic on milk production can clearly be attributed to the decreased DMI, the trend for decreased milk yield with the other PN is difficult to explain. Specific plant extracts and PN may have an objectionable odor and decrease DMI through palatability mechanisms when offered mixed with the TMR (a clear example with carvacrol in oregano was reported by Hristov et al., 2013), but apparently this could not have been the case in the current study because PN were infused into the abomasum. Thus, the mechanism involved in the decreased milk production with all PN remains unclear. In studies with rats, capsaicin increased energy expenditure by enhancing adrenal sympathetic nerve activity and epinephrine secretion (Kawada et al., 1986; Watanabe et al., 1987, 1988). Similarly, an oral dose of red pepper containing capsaicin induced thermogenesis and increased heat loss in humans (Hachiya et al., 2007). These properties of capsaicin could have caused less-efficient use of dietary energy, which might have resulted in the decreased milk production observed in the current study. Variable effects on DMI by essential oil preparations have been reported for dairy cows in the literature (Kung et al., 2008; Tassoul and Shaver, 2009; Tager and Krause, 2011).

Similar to the feed intake and production data, no dairy cow studies are known to us that investigated digestibility and urinary $\mathrm{N}$ loss effects of PN supplied postruminally. Several studies have reported a lack of effect of PN, specifically various blends of essential oils 
Table 6. Effect of phytonutrients on T-cell phenotypes, proliferation, viability, and cytokine production of peripheral blood mononuclear cells (PBMC) in dairy cows (LSM)

\begin{tabular}{|c|c|c|c|c|c|c|}
\hline \multirow[b]{2}{*}{ Item } & \multicolumn{4}{|c|}{ Treatment $^{1}$} & \multirow[b]{2}{*}{$\mathrm{SEM}^{2}$} & \multirow[b]{2}{*}{$P$-value ${ }^{3}$} \\
\hline & Control & Curcumin & Garlic & Capsicum & & \\
\hline \multicolumn{7}{|c|}{ T cell phenotypes, $\%$} \\
\hline$\gamma \delta^{+} \mathrm{WC} 1^{-}$ & 4.05 & 4.73 & 5.19 & 4.16 & 0.734 & 0.36 \\
\hline$\gamma \delta^{-} \mathrm{WC}^{+}$ & 0.75 & 0.59 & 0.61 & 0.48 & 0.205 & 0.84 \\
\hline$\gamma \delta^{+} \mathrm{WC}^{+}$ & 8.69 & 8.92 & 9.56 & 9.04 & 1.963 & 0.90 \\
\hline Total $\mathrm{WC1}^{+}$ & 9.44 & 9.51 & 10.1 & 9.52 & 2.024 & 0.92 \\
\hline Total $\gamma \delta^{+}$ & 12.7 & 13.7 & 14.7 & 13.2 & 2.47 & 0.55 \\
\hline $\mathrm{CD} 4^{+} \mathrm{CD} 25^{-}$ & $10.3^{\mathrm{b}}$ & $16.9^{\mathrm{a}}$ & $14.8^{\mathrm{a}}$ & $14.4^{\mathrm{a}}$ & 1.55 & 0.03 \\
\hline $\mathrm{CD} 4^{-} \mathrm{CD} 25^{+}$ & 3.12 & 3.19 & 2.43 & 4.15 & 1.325 & 0.86 \\
\hline $\mathrm{CD} 4^{+} \mathrm{CD} 25^{+}$ & 1.57 & 3.19 & 3.55 & 3.36 & 0.717 & 0.28 \\
\hline Total CD4 $4^{+}$ & $11.9^{\mathrm{b}}$ & $20.3^{\mathrm{a}}$ & $18.4^{\mathrm{a}}$ & $17.8^{\mathrm{a}}$ & 1.86 & 0.02 \\
\hline Total CD $25^{+}$ & 4.71 & 6.52 & 6.00 & 7.54 & 1.729 & 0.75 \\
\hline$\gamma \delta^{+} \mathrm{ACT} 2^{-}$ & 10.4 & 10.5 & 9.52 & 7.82 & 2.159 & 0.66 \\
\hline$\gamma \delta^{-} \mathrm{ACT}^{+}$ & 7.29 & 6.38 & 5.58 & 7.18 & 2.126 & 0.95 \\
\hline$\gamma \delta^{+} \mathrm{ACT}_{2}^{+}$ & 5.52 & 5.00 & 4.17 & 4.69 & 0.923 & 0.77 \\
\hline Total ACT2 $2^{+}$ & 12.8 & 11.4 & 9.75 & 11.9 & 2.409 & 0.87 \\
\hline Total $\gamma \delta+$ & 15.9 & 15.5 & 13.7 & 12.5 & 2.62 & 0.65 \\
\hline $\mathrm{CD} 8 \alpha^{+} \mathrm{ACT}_{2}^{-}$ & 8.08 & 9.40 & 8.45 & 7.25 & 1.662 & 0.83 \\
\hline $\mathrm{CD} 8 \alpha^{-} \mathrm{ACT}^{+}$ & 7.04 & 8.39 & 7.73 & 10.5 & 2.321 & 0.74 \\
\hline $\mathrm{CD} \alpha^{+} \mathrm{ACT}^{+}$ & 3.90 & 3.08 & 3.43 & 4.17 & 1.487 & 0.95 \\
\hline Total CD $8 \alpha^{+}$ & 12.0 & 12.5 & 11.9 & 11.4 & 2.68 & 0.99 \\
\hline Total ACT2+ & 10.9 & 11.5 & 11.2 & 14.7 & 3.51 & 0.86 \\
\hline $\mathrm{CD} 8 \alpha^{+} \gamma \delta^{-}$ & 6.67 & 7.75 & 7.11 & 6.36 & 1.011 & 0.68 \\
\hline $\mathrm{CD} 8 \alpha^{-} \gamma \delta^{+}$ & 11.4 & 12.2 & 12.7 & 12.7 & 2.32 & 0.74 \\
\hline $\mathrm{CD} 8 \alpha^{+} \gamma \delta^{+}$ & 1.98 & 1.82 & 1.81 & 1.72 & 0.408 & 0.91 \\
\hline Total CD8 ${ }^{+}$ & 8.65 & 9.57 & 8.92 & 8.08 & 1.325 & 0.78 \\
\hline Total $\gamma \delta+$ & 13.4 & 14.1 & 14.5 & 14.4 & 2.59 & 0.87 \\
\hline $\mathrm{CD} 8 \alpha^{+} \mathrm{CD} 8 \beta^{-}$ & 5.05 & 5.68 & 5.27 & 6.27 & 1.700 & 0.95 \\
\hline $\mathrm{CD} 8 \alpha^{-} \mathrm{CD} 8 \beta^{+}$ & 1.80 & 1.27 & 1.15 & 1.54 & 0.635 & 0.84 \\
\hline $\mathrm{CD} \alpha^{+} \mathrm{CD} \beta^{+}$ & 6.25 & 8.93 & 8.59 & 7.96 & 1.130 & 0.24 \\
\hline Total CD8 $\alpha^{+}$ & 11.4 & 14.6 & 13.7 & 14.3 & 2.58 & 0.76 \\
\hline Total CD $8 \beta^{+}$ & 8.03 & 10.2 & 9.73 & 9.47 & 1.085 & 0.39 \\
\hline $\mathrm{WC}^{+}{ }^{+} \mathrm{CD} 25^{-}$ & 8.40 & 7.34 & 8.49 & 8.27 & 1.797 & 0.85 \\
\hline $\mathrm{WC}^{-} \mathrm{CD}^{2} 5^{+}$ & 3.53 & 4.50 & 4.75 & 3.75 & 0.948 & 0.81 \\
\hline $\mathrm{WC}^{+}{ }^{+} \mathrm{CD} 25^{+}$ & 1.11 & 2.14 & 1.29 & 1.90 & 0.713 & 0.71 \\
\hline Total $\mathrm{WC1}^{+}$ & 9.52 & 9.48 & 9.78 & 10.2 & 1.991 & 0.95 \\
\hline Total CD $25^{+}$ & 4.64 & 6.64 & 6.04 & 5.65 & 1.481 & 0.84 \\
\hline \multicolumn{7}{|c|}{ PBMC proliferation, $\%$} \\
\hline No Con $A^{4}$ & 4.62 & 11.2 & 15.0 & 16.6 & 4.21 & 0.24 \\
\hline Con A & 41.9 & 41.2 & 48.4 & 48.6 & 10.96 & 0.92 \\
\hline \multicolumn{7}{|l|}{ PBMC viability, $\%$} \\
\hline No Con A & 82.2 & 82.0 & 81.7 & 79.8 & 7.00 & 0.99 \\
\hline Con A & 84.3 & 86.9 & 88.5 & 86.9 & 4.15 & 0.88 \\
\hline \multicolumn{7}{|c|}{ Cytokines production ${ }^{5}$} \\
\hline \multicolumn{7}{|c|}{ IL6, ng/mL } \\
\hline IL6, no LPS & 0.13 & 0.13 & 0.11 & 0.12 & 0.019 & 0.59 \\
\hline IL6, LPS & 0.33 & 0.34 & 0.31 & 0.27 & 0.031 & 0.49 \\
\hline \multicolumn{7}{|l|}{ IFNG, ng/mL } \\
\hline IFNG, no LPS & 0.78 & 0.84 & 0.67 & 0.68 & 0.094 & 0.54 \\
\hline IFNG, LPS & 0.80 & 0.95 & 1.18 & 0.85 & 0.172 & 0.46 \\
\hline \multicolumn{7}{|l|}{$\mathrm{TNF}, \mathrm{pg} / \mathrm{mL}$} \\
\hline TNF, no LPS & 1.04 & 1.17 & 0.96 & 0.88 & 0.094 & 0.27 \\
\hline TNF, LPS & 1.41 & 1.98 & 1.91 & 1.97 & 0.234 & 0.35 \\
\hline
\end{tabular}

${ }^{\mathrm{a}, \mathrm{b}}$ Within a row, means without a common superscript letter differ $(P<0.05)$.

${ }^{1}$ Control = abomasal administration of $290 \mathrm{~mL} /$ cow per day of ethanol solution; curcumin = abomasal administration of $2 \mathrm{~g} / \mathrm{cow}$ per day of curcuma oleoresin dissolved in $290 \mathrm{~mL}$ of ethanol solution; garlic = abomasal administration of $2 \mathrm{~g} / \mathrm{d}$ of garlic extract dissolved in $290 \mathrm{~mL}$ of ethanol solution; capsicum = abomasal administration of $2 \mathrm{~g} / \mathrm{d}$ of capsicum oleoresin dissolved in $290 \mathrm{~mL}$ of ethanol solution.

${ }^{2}$ Highest SEM shown; $\mathrm{n}=24$ to 32 (n represents number of observations used in the statistical analysis).

${ }^{3}$ Main effect of treatment.

${ }^{4}$ Concanavalin A.

${ }^{5} \mathrm{IFNG}=$ interferon- $\gamma$; TNF $=$ tumor necrosis factor $\alpha$. 
Table 7. Effect of phytonutrients on expression of mRNA in liver for key enzymes (LSM) in dairy cows ${ }^{1}$

\begin{tabular}{|c|c|c|c|c|c|c|}
\hline \multirow[b]{2}{*}{ Item } & \multicolumn{4}{|c|}{ Treatment $^{2}$} & \multirow[b]{2}{*}{$\mathrm{SEM}^{3}$} & \multirow[b]{2}{*}{$P$-value ${ }^{4}$} \\
\hline & Control & Curcumin & Garlic & Capsicum & & \\
\hline Pyruvate carboxylase & 0.82 & 1.17 & 1.28 & 1.37 & 0.686 & 0.95 \\
\hline Phosphoenolpyruvate carboxykinase-C & 1.88 & 2.86 & 2.12 & 1.81 & 0.816 & 0.74 \\
\hline Glucose 6-phosphatase & 1.03 & 1.61 & 1.38 & 1.71 & 0.379 & 0.63 \\
\hline Carnitine palmitoyltransferase-1A & 1.22 & 0.90 & 1.01 & 1.36 & 0.378 & 0.84 \\
\hline Catalase & 1.49 & 1.48 & 1.42 & 1.53 & 0.470 & 1.00 \\
\hline Glutathionine peroxidase & 2.09 & 2.52 & 3.03 & 3.56 & 0.718 & 0.57 \\
\hline$\alpha-2$-Macroglobulin & 0.70 & 0.40 & 0.46 & 0.39 & 0.208 & 0.65 \\
\hline
\end{tabular}

${ }^{1}$ Arbitrary units; normalized to $18 \mathrm{~S}$ mRNA abundance. Total copies of each mRNA were divided by the total copies of 18S mRNA (White et al., 2011).

${ }^{2}$ Control = abomasal administration of $290 \mathrm{~mL} /$ cow per day of ethanol solution; curcumin = abomasal administration of $2 \mathrm{~g} / \mathrm{cow}$ per day of curcuma oleoresin dissolved in $290 \mathrm{~mL}$ of ethanol solution; garlic = abomasal administration of $2 \mathrm{~g} / \mathrm{d}$ of garlic extract dissolved in $290 \mathrm{~mL}$ of ethanol solution; capsicum = abomasal administration of $2 \mathrm{~g} / \mathrm{d}$ of capsicum oleoresin dissolved in $290 \mathrm{~mL}$ of ethanol solution.

${ }^{3}$ Highest SEM shown; $\mathrm{n}=31$ to 32 (n represents number of observations used in the statistical analysis).

${ }^{4}$ Main effect of treatment.

or their active ingredients, on ruminal or total-tract nutrient digestibility (Benchaar et al., 2007; Tager and Krause, 2011) or urinary N losses (Benchaar et al., 2006, 2007). In some cases, however, DM or fiber degradability and digestibility were remarkably increased (Benchaar et al., 2006; Yang et al., 2007; about a 12\% increase in OM degradability with garlic essential oils in Boyd et al., 2012). In the current study, postruminal supplementation of $2 \mathrm{~g} / \mathrm{d}$ of PN had no effect on totaltract digestibility or urinary $\mathrm{N}$ losses.

Gut digesta or tissue could not be sampled in the current study and, therefore, fecal samples were used to assess the effect of PN on intestinal microflora. Bacterial composition of fecal matter is closely related to

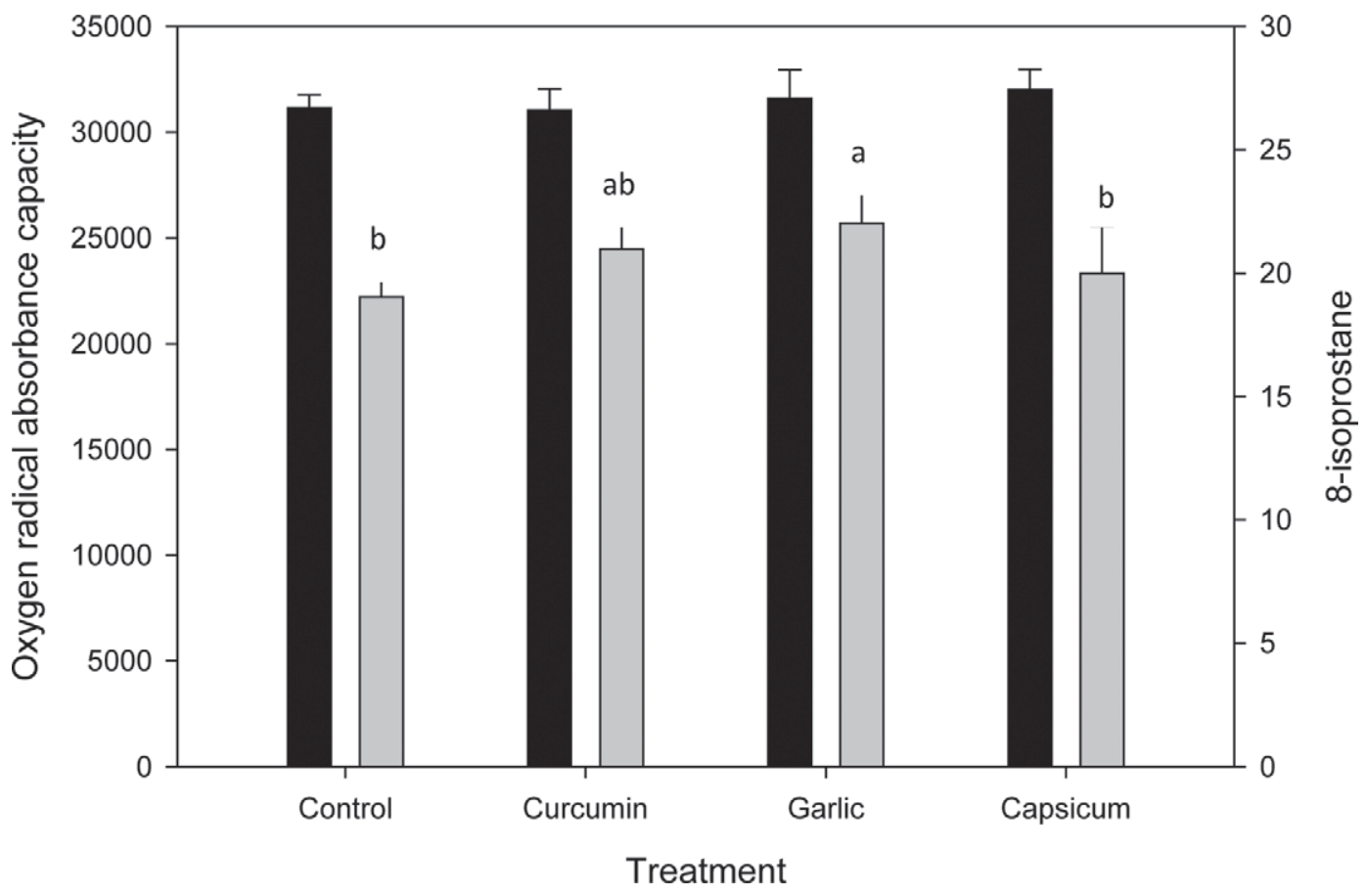

Figure 1. Effect of phytonutrients on oxidative stress markers in blood of dairy cows (means \pm SE). Control = abomasal administration of $290 \mathrm{~mL} /$ cow per day of ethanol solution; curcumin = abomasal administration of $2 \mathrm{~g} / \mathrm{cow}$ per day of curcuma oleoresin dissolved in $290 \mathrm{~mL}$ of ethanol solution; garlic = abomasal administration of $2 \mathrm{~g} / \mathrm{d}$ of garlic extract dissolved in $290 \mathrm{~mL}$ of ethanol solution; capsicum $=$ abomasal administration of $2 \mathrm{~g} / \mathrm{d}$ of capsicum oleoresin dissolved in $290 \mathrm{~mL}$ of ethanol solution. Oxygen radical absorbance capacity (ORAC, black bars) is shown in Trolox equivalent units and 8-isoprostane (gray bars) is in picograms per milliliter. Overall effect of treatment $(\mathrm{n}=64 ; \mathrm{n}$ represents number of observations used in the statistical analysis), $P=0.84$ and 0.02 (ORAC and 8-isoprostane, respectively; SEM $=993.0$ and 1.99 , respectively). ${ }^{\mathrm{a}, \mathrm{b}}$ Within variable, bars without a common letter differ $(P<0.05)$. 
the microfloral composition of the cecum in vertebrate animals (Smith, 1965), and fecal microbial cultures have been routinely used to study intestinal microbial composition (Tannock, 2001). The only genus that was numerically affected by PN in the current study was Oscillospira. These large bacteria are common inhabitants of the rumen and large intestine of cattle (Mackie et al., 2003; Li et al., 2012), and their decreased population in feces is likely an indication of decreased large intestinal populations. The implications of this observation, however, are unclear.

The only difference in blood cells in this study was a slight increase in the proportion of lymphocytes in the total white blood cells with the curcumin and capsicum treatments. This increase was likely due to a slightly lower total white blood cell count in these treatments compared with the control and a slight decrease in neutrophil count, resulting in a relatively greater percentage of lymphocytes in these treatments. However, white blood cell counts were within the normal variable range for adult cattle (Weiss and Wardrop, 2010). The neutrophil:lymphocyte ratio for the curcumin and capsicum treatments (arithmetic means of 1.34 and 1.31, respectively) were similar to that of the control (1.36), whereas the neutrophil:lymphocyte ratio in the garlic treatment was slightly higher $(1.56 ; P=0.02$; SEM $=0.288)$. This increase was suggested as indicative of an acute stress response (Weiss and Wardrop, 2010). Whether or not cattle on the garlic treatment experienced a stronger acute stress response compared with the control or the other PN treatments is unknown but may be of interest to explore in future research. Feng et al. (2012) indicated that allicin, a major active component of garlic, enhances proinflammatory responses in acute phase infection by parasite in mice (Mus spp.). In contrast, Kuo et al. (2011) reported that garlic oil has an antiinflammatory effect on neutrophil infiltration by lowering adhesion molecules in rats (Rattus spp.).

The activity of peripheral blood immune cells measured by proliferation and cytokine production ex vivo was not significantly affected by any of the PN tested in the present study. However, further analysis of PBMC revealed that the proportion of $\mathrm{CD}^{+}$cells increased in response to garlic, curcumin, and capsicum treatments compared with the control. This indicates that compared with other immune cells in peripheral blood, $\mathrm{CD} 4^{+}$cells may be more sensitive to the effects of $\mathrm{PN}$. Although not statistically significant, all PN also doubled the proportion of $\mathrm{CD} 4^{+}$cells that co-expressed CD25 $\alpha$ (the high affinity receptor for IL2). Indeed, $\mathrm{CD} 25 \alpha$ is considered an indicator of the activation status of bovine $\mathrm{T}$ lymphocytes (Waters et al., 2003). Dietary supplementation of garlic in a fermented form enhanced the proportion of $\mathrm{CD} 4^{+}$in $\mathrm{T}$ lymphocytes isolated from pigs (Sus scrofa domesticus) challenged with and without LPS (Wang et al., 2011). Garlic has been shown to induce proliferation of human PBMC (Salman et al., 1999), rat T lymphocytes (Colić et al., 2002), and mouse splenocytes (Patya et al., 2004) in vitro. In the present study, the lack of a significant effect of garlic on proliferation may be attributed to both the variation in individual animal responses and the concentration of garlic in peripheral circulation. In vitro studies have shown that garlic increases the expression of CD25 in rat splenocytes stimulated with either phorbol myristate acetate or concanavalin A (Colić and Savić, 2000; Liu et al., 2009). Diets supplemented with both capsicum and curcumin increased splenocyte proliferation and peripheral blood CD4 ${ }^{+}$cells in chicken (Gallus gallus domesticus) challenged with Eimeria tenella (Lee et al., 2011). Curcumin alone has also been shown to increase mouse $\mathrm{CD}^{+}$cells in the spleen (Yasni et al., 1993) and intestinal mucosa (Churchill et al., 2000). In experimental autoimmune encephalomyelitis, curcumin increased mouse $\mathrm{CD} 4^{+} \mathrm{CD} 25^{+}$T-regulatory cells in the spleen (Kanakasabai et al., 2012). However, curcumin has also been shown to inhibit the expansion of splenic $\mathrm{CD}^{+}$cells and their expression of CD25 in vitro (Forward et al., 2011). In the present study, it was not determined if the $\mathrm{CD} 4^{+} \mathrm{CD} 25^{+}$population were regulatory $\mathrm{T}$ cells. When CD4 T lymphocytes are activated, they produce cytokines that activate cells of the innate immune system such as macrophages, and stimulate antibody production from B cells. However, the induction of TNF, IFN $\gamma$, and IL6 with LPS in vitro was not affected by $\mathrm{PN}$ in the current study. Although the nature of the immune response cannot be characterized as pro- or antiinflammatory, garlic, curcumin, and capsicum might modulate the function of the adaptive immune system, as reported in monogastric species.

Liver has been recognized as a potential site of action for curcumin (Maradana et al., 2013), capsicum (Kang et al., 2011), and garlic oils (Iciek et al., 2012), and these PN act to improve lipid metabolism, insulin sensitivity, and enhanced capacity to respond to oxidative stressors in the attenuation of metabolic dysregulation caused by obesity (Kang et al., 2011) or excessive alcohol consumption (Raghu et al., 2012). Several PN have been shown to be safe and effective in enhancing metabolism, but the blood concentrations necessary to elicit a biological response are difficult to attain using oral supplementation due to low bioavailability, causing a combination of poor absorption, rapid metabolism, and rapid systemic elimination (Anand et al., 2007; Ferruzzi, 2010). Methods are being actively sought to enhance PN bioavailability through the use of nanoparticles, chemically enhanced derivatives, and other technologies (Anand et al., 2007). Although the 
effect of rumen metabolism on PN was circumvented in the present study by abomasal infusion, we did not attempt to enhance postruminal bioavailability; consequently, the PN used are subject to the same limitations observed in monogastric species. The lack of observed response for liver transcripts and other postabsorptive measures in the present experiment may reflect a lack of bioavailability, a lack of efficacy, or a combination of both. Additional measures of circulating PN and secondary metabolites are necessary to adequately assess bioavailability. Likewise, the use of in vitro models of hepatic metabolism are needed to directly assess the effect of PN on bovine hepatic metabolism to more fully determine the potential of PN to enhance metabolism in dairy cows.

Many studies have reported evidence that PN, such as the phenolics found in garlic, curcumin, and capsicum, elicit an antiinflammatory effect when consumed as dietary components. These effects are commonly attributed to the potent radical scavenging activity of phenolic compounds, which is thought to translate to antioxidant activity in vivo. Indeed, phenolics exhibit potent antioxidant activity in vitro; however, it has been much harder to demonstrate such activity in vivo. In fact, several studies have shown that the consumption of high levels (e.g., pharmacological doses) of polyphenols such as flavonoids can have deleterious consequences in monogastric species-hepatic and intestinal toxicity, DNA damage, and leukemogenic effects (Lambert et al., 2007); however, we are unaware of any study that demonstrates such an effect in ruminant species. A likely and generally well-accepted mechanism for the proinflammatory and pro-oxidative effect of dietary phenolics is hydrogen peroxide generation (i.e., oxygen reduction) coupled with phenolic oxidation. Hydrogen peroxide and its metal-catalyzed reduction products (e.g., hydroxyl radicals) are capable of damaging biological molecules such as membrane components, proteins, and DNA (Lambert and Elias, 2010). A second potential mechanism that could explain the absence of an observed antioxidant effect of $\mathrm{PN}$ in this study and, in the case of 8-isoprostane levels, a slight increase in pro-oxidant activity, is the generation of $o$-quinones from phenolic oxidation. As highly electrophilic compounds, quinones are known to react with and consume nucleophiles in vivo (Sang et al., 2005), some of which are important antioxidant factors (e.g., glutathione).

\section{CONCLUSIONS}

The PN used in this study - curcumin, garlic extract, and capsicum - when administered postruminally at 2 $\mathrm{g} /$ cow per day had subtle or no effects on blood cells and chemistry, nutrient digestibility, fecal bacterial diversity, antioxidant status, or expression of mRNA in liver for key enzymes in dairy cows. These PN, however, appeared to have an immune-stimulatory effect by activating and inducing the expansion of CD4 cells. The production and other effects observed in the study should be interpreted with caution because of the short duration of the PN treatment.

\section{ACKNOWLEDGMENTS}

The authors thank Pancosma S.A. (Geneva, Switzerland) for providing partial financial support for this project and the phytonutrients used in the experiment, and thank the staff of the Department of Animal Science Dairy Center (The Pennsylvania State University, University Park) for their conscientious care of the experimental cows.

\section{REFERENCES}

Anand, P., A. B. Kunnumakkara, R. A. Newman, and B. B. Aggarwal. 2007. Bioavailability of curcumin: Problems and promises. Mol. Pharm. 4:807-818.

Ando, S., T. Nishida, M. Ishida, K. Hosoda, and E. Bayaru. 2003. Effect of peppermint feeding on the digestibility, ruminal fermentation and protozoa. Livest. Prod. Sci. 82:245-248.

Applegate, T. J. 2009. Influence of phytogenics on the immunity of livestock and poultry. Pages 39-59 in Phytogenics in Animal Nutrition. T. Steiner, ed. Nottingham University Press, Nottingham, UK.

Bakkali, F., S. Averbeck, D. Averbeck, and M. Idaomar. 2008. Biological effects of essential oils-A review. Food Chem. Toxicol. 46:446-475.

Benchaar, C., H. V. Petit, R. Berthiaume, D. R. Ouellet, J. Chiquette, and P. Y. Chouinard. 2007. Effects of essential oils on digestion, ruminal fermentation, rumen microbial populations, milk production, and milk composition in dairy cows fed alfalfa silage or corn silage. J. Dairy Sci. 90:886-897.

Benchaar, C., H. V. Petit, R. Berthiaume, T. D. Whyte, and P. Y. Chouinard. 2006. Effects of addition of essential oils and monensin premix on digestion, ruminal fermentation, milk production and milk composition in dairy cows. J. Dairy Sci. 89:4352-4364.

Boyd, J., J. W. West, J. K. Bernard, and S. S. Block. 2012. Effects of plant extracts on milk yield and apparent efficiency of lactating dairy cows during hot weather. Prof. Anim. Sci. 28:338-343.

Cao, G., and R. L. Prior. 1999. Measurement of oxygen radical absorbance capacity in biological samples. Methods Enzymol. 299:5062.

Churchill, M., A. Chadburn, R. T. Bilinski, and M. M. Bertagnolli. 2000. Inhibition of intestinal tumors by curcumin is associated with changes in the intestinal immune cell profile. J. Surg. Res. $89: 169-175$.

Colić, M., and M. Savić. 2000. Garlic extracts stimulate proliferation of rat lymphocytes in vitro by increasing IL-2 and IL-4 production. Immunopharmacol. Immunotoxicol. 22:163-181.

Colić, M., D. Vucević, V. Kilibarda, N. Radicević, and M. Savić. 2002. Modulatory effects of garlic extracts on proliferation of T-lymphocytes in vitro stimulated with concanavalin A. Phytomedicine 9:117-124.

Cowan, M. M. 1999. Plant products as antimicrobial agents. Clin. Microbiol. Rev. 12:564-582.

Dowd, S. E., T. R. Callaway, Y. Sun, T. McKeehan, R. G. Hagevoort, and T. S. Edrington. 2008a. Evaluation of the bacterial diversity in the feces of cattle using bacterial tag-encoded FLX amplicon pyrosequencing (bTEFAP). BMC Microbiol. 8:125-132. 
Dowd, S. E., Y. Sun, P. R. Secor, D. D. Rhoads, B. M. Wolcott, G. A. James, and R. D. Wolcott. 2008b. Survey of bacterial diversity in chronic wounds using pyrosequencing, DGGE, and full ribosome shotgun sequencing. BMC Microbiol. 8:43-58.

Feng, Y., X. Zhu, Q. Wang, Y. Jiang, H. Shang, L. Cui, and Y. Cao. 2012. Allicin enhances host pro-inflammatory immune responses and protects against acute murine malaria infection. Malar. J. 11:268-296.

Ferruzzi, M. G. 2010. The influence of beverage composition on delivery of phenolic compounds from coffee and tea. Physiol. Behav. 100:33-41.

Forward, N. A., D. M. Conrad, M. R. Power Coombs, C. D. Doucette, S. J. Furlong, T. J. Lin, and D. W. Hoskin. 2011. Curcumin blocks interleukin (IL)-2 signaling in T-lymphocytes by inhibiting IL-2 synthesis, CD25 expression, and IL-2 receptor signaling. Biochem. Biophys. Res. Commun. 407:801-806.

Franz, C., K. H. C. Baser, and W. Windisch. 2010. Essential oils and aromatic plants in animal feeding - A European perspective. A review. Flavour Fragrance J. 25:327-340.

Giannenas, I., and I. Kyriazakis. 2009. Phytobased products for the control of intestinal diseases in chickens in the post antibiotic era. Pages 61-85 in Phytogenics in Animal Nutrition. T. Steiner, ed. Nottingham University Press, Nottingham, UK.

Greathead, H. 2003. Plants and plant extracts for improving animal productivity. Proc. Nutr. Soc. 62:279-290.

Greenfield, R. B., M. J. Cecava, and S. S. Donkin. 2000. Changes in mRNA expression for gluconeogenic enzymes in liver of dairy cattle during the transition to lactation. J. Dairy Sci. 83:1228-1236.

Guo, F. C., R. P. Kwakkel, J. Soede, B. A. Williams, and M. W. A Vestegen. 2004a. Effect of a Chinese herb medicine formulation, as an alternative for antibiotics, on performance of broilers. Br. Poult. Sci. 45:793-797.

Guo, F. C., B. A. Williams, R. P. Kwakkel, H. S. Li, X. P. Li, J Y. Luo, W. K. Li, and M. W. A. Verstegen. 2004b. Effects of mushroom and herb polysaccharides, as alternatives for antibiotic, on the cecal microbial ecosystem in broiler chickens. Poult. Sci. $83: 175-182$.

Hachiya, S., F. Kawabata, K. Ohnuki, N. Inoue, H. Yoneda, S. Yazawa, and T. Fushiki. 2007. Effects of CH-19 Sweet, a non-pungent cultivar of red pepper, on sympathetic nervous activity, body temperature, heart rate, and blood pressure in humans. Biosci. Biotechnol. Biochem. 71:671-676.

Hristov, A. N., S. Ahvenjarvi, P. Huhtanen, and T. A. McAllister 2003. Composition and digestive tract retention time of ruminal particles with functional specific gravity greater or less than 1.02 . J. Anim. Sci. 81:2639-2648

Hristov, A. N., C. Lee, T. Cassidy, K. Heyler, J. A. Tekippe, G. A. Varga, B. Corl, and R. C. Brandt. 2013. Effect of Origanum vulgare L. leaves on rumen fermentation, production, and milk fatty acid composition in lactating dairy cows. J. Dairy Sci. 96:1189-1202.

Hristov, A. N., C. Lee, T. Cassidy, M. Long, B. Corl, and R. Forster. 2011. Effects of lauric and myristic acids on ruminal fermentation, production, and milk fatty acid composition in lactating dairy cows. J. Dairy Sci. 94:382-395.

Huhtanen, P., K. Kaustell, and S. Jaakkola. 1994. The use of internal markers to predict total digestibility and duodenal flow of nutrients in cattle given six different diets. Anim. Feed Sci. Technol. 48:211-227.

Iciek, M. B., D. Kowalczyk-Pachel, I. Kwiecień, and M. B. Dudek. 2012. Effects of different garlic-derived allyl sulfides on peroxidative processes and anaerobic sulfur metabolism in mouse liver. Phytother. Res. 26:425-431.

Jouany, J.-P., and D. P. Morgavi. 2007. Use of 'natural' products as alternatives to antibiotic feed additives in ruminant production. Animal 1:1443-1466.

Ju, J., X. P. Hao, M. J. Lee, J. D. Lambert, G. Lu, H. Xiao, H. L. Newmark, and C. S. Yang. 2009. A gamma-tocopherol-rich mixture of tocopherols inhibits colon inflammation and carcinogenesis in azoxymethane and dextran sulfate sodium-treated mice. Cancer Prev. Res. (Phila.) 2:143-152.
Kanakasabai, S., E. Casalini, C. C. Walline, C. Mo, W. Chearwae, and J. J. Bright. 2012. Differential regulation of CD4+ T helper cell responses by curcumin in experimental autoimmune encephalomyelitis. J. Nutr. Biochem. 23:1498-1507.

Kang, J. H., G. Tsuyoshi, H. Le Ngoc, H. M. Kim, T. H. Tu, H. J. Noh, C. S. Kim, S. Y. Choe, T. Kawada, H. Yoo, and R. Yu. 2011. Dietary capsaicin attenuates metabolic dysregulation in genetically obese diabetic mice. J. Med. Food 14:310-315.

Kawada, T., T. Watanabe, T. Takaishi, T. Tanaka, and K. Iwai. 1986. Capsaicin-induced beta-adrenergic action on energy metabolism in rats: Influence of capsaicin on oxygen consumption, the respiratory quotient, and substrate utilization. Proc. Soc. Exp. Biol. Med. 183:250-256.

Kung, L., Jr., P. Williams, R. J. Schmidt, and W. Hu. 2008. A blend of essential plant oils used as an additive to alter silage fermentation or used as a feed additive for lactating dairy cows. J. Dairy Sci. 91:4793-4800.

Kuo, C., S. Lee, K. Chen, C. Lii, and C. Liu. 2011. Effect of garlic oil on neutrophil infiltration in the small intestine of endotoxininjected rats and its association with levels of soluble and cellular adhesion molecules. J. Agric. Food Chem. 59:7717-7725.

Lambert, J. D., and R. J. Elias. 2010. The antioxidant and pro-oxidant activities of green tea polyphenols: A role in cancer prevention. Arch. Biochem. Biophys. 501:65-72.

Lambert, J. D., S. Sang, and C. S. Yang. 2007. Possible controversy over dietary polyphenols: Benefits vs risks. Chem. Res. Toxicol 20:583-585.

Lang, A., M. Lahav, E. Sakhnini, I. Barshack, H. H. Fidder, B. Avidan, E. Bardan, R. Hershkoviz, S. Bar-Meir, and Y. Chowers. 2004. Allicin inhibits spontaneous and TNF- $\alpha$ induced secretion of proinflammatory cytokines and chemokines from intestinal epithelial cells. Clin. Nutr. 23:1199-1208.

Lee, C., A. N. Hristov, T. W. Cassidy, K. S. Heyler, H. Lapierre, G. A. Varga, M. J. de Veth, R. A. Patton, and C. Parys. 2012. Rumenprotected lysine, methionine, and histidine increase milk protein yield in dairy cows fed metabolizable protein-deficient diet. J. Dairy Sci. 95:6042-6056.

Lee, S. H., H. S. Lillehoj, S. I. Jang, K. W. Lee, D. Bravo, and E. P. Lillehoj. 2011. Effects of dietary supplementation with phytonutrients on vaccine-stimulated immunity against infection with Eimeria tenella. Vet. Parasitol. 181:97-105.

Lejonklev, J., M. M. Løkke, M. K. Larsen, G. Mortensen, M. A. Petersen, and M. R. Weisbjerg. 2013. Transfer of terpenes from essential oils into cow milk. J. Dairy Sci. 96:4235-4241.

Li, Y., L. Hu, G. Xue, H. Liu, H. Yang, Y. Zhu, Y. Tian, and X. Lu. 2012. Comparison of bacterial diversity in large intestine of Xiangxi yellow cattle (Bos taurus) associated with different diet: Fresh Miscanthus sinensis and mixed forage. Afr. J. Microbiol. Res. 6:5965-5974.

Liu, C. T., H. M. Su, C. K. Lii, and L. Y. Sheen. 2009. Effect of supplementation with garlic oil on activity of Th1 and Th2 lymphocytes from rats. Planta Med. 75:205-210.

Maass, N., J. Bauer, B. R. Paulicks, B. M. Böhmer, and D. A. RothMaier. 2005. Efficiency of Echinacea purpurea on performance and immune status in pigs. J. Anim. Physiol. Anim. Nutr. (Berl.) $89: 244-252$

Mackie, R. I., R. I. Aminov, W. Hu, A. V. Klieve, D. Ouwerkerk, M. A. Sundset, and Y. Kamagata. 2003. Ecology of uncultivated Oscillospira species in the rumen of cattle, sheep, and reindeer as assessed by microscopy and molecular approaches. Appl. Environ. Microbiol. 69:6808-6815.

Maradana, M. R., R. Thomas, and B. J. O'Sullivan. 2013. Targeted delivery of curcumin for treating type 2 diabetes. Mol. Nutr. Food Res. 57:1550-1556. http://dx.doi.org/10.1002/mnfr.201200791.

Michiels, J., J. Missotten, N. Dierick, D. Fremaut, and S. de Smet. 2005. Antimicrobial activity of selected phytochemicals against the pig gut flora. Commun. Agric. Appl. Biol. Sci. 70:191-194.

Michiels, J., J. Missotten, D. Fremaut, S. de Smet, and N. Dierick. 2007. In vitro dose-response of carvacrol, thymol, eugenol and trans-cinnamaldehyde and interaction of combinations for the an- 
timicrobial activity against the pig gut flora. Livest. Sci. 109:157160.

Mirunalini, S., G. Dhamodharan, and K. Karthishwaran. 2010. A natural wonder drug helps to prevent cancer: Garlic oil. Notulae Scientia Biologicae 2:14-19.

Ndiaye, K., D. Poole, and J. L. Pate. 2008. Expression and regulation of functional oxytocin receptors in bovine T lymphocytes. Biol. Reprod. 78:786-793.

NRC. 2001. Nutrient Requirements of Dairy Cattle. 7th rev. ed. Natl. Acad. Sci., Washington, DC.

Panda, K., S. V. Rama Rao, and M. V. L. N. Raju. 2006. Natural growth promoters have potential in poultry feeding systems. Feed Technol. 10:23-25.

Patya, M., M. A. Zahalka, A. Vanichkin, A. Rabinkov, T. Miron, D. Mirelman, M. Wilchek, H. M. Lander, and A. Novogrodsky. 2004. Allicin stimulates lymphocytes and elicits an antitumor effect: Apossible role of $\mathrm{p} 21^{\text {ras }}$. Int. Immunol. 16:275-281.

Poole, D. H., and J. L. Pate. 2012. Luteal microenvironment directs resident $\mathrm{T}$ lymphocyte function in cows. Biol. Reprod. 86:29.http://dx.doi.org/10.1095/biolreprod.111.092296.

Raghu, R., C. T. Liu, M. H. Tsai, X. Tang, K. R. Kalari, S. Subramanian, and L. Y. Sheen. 2012. Transcriptome analysis of garlicinduced hepatoprotection against alcoholic fatty liver. J. Agric. Food Chem. 60:11104-11119.

Rochfort, S., A. J. Parker, and F. Dunshea. 2008. Plant bioactives for ruminant health and productivity. Phytochemistry 69:299-322.

Salman, H., M. Bergman, H. Bessler, I. Punsky, and M. Djaldetti 1999. Effect of a garlic derivative (alliin) on peripheral blood cell immune responses. Int. J. Immunopharmacol. 21:589-597.

Sang, S., J. D. Lambert, J. Hong, S. Tian, M. J. Lee, R. E. Stark, C. T. Ho, and C. S. Yang. 2005. Synthesis and structure identification of thiol conjugates of (-)-epigallocatechin gallate and their urinary levels in mice. Chem. Res. Toxicol. 18:1762-1769.

Schneider, B. H., and W. P. Flatt. 1975. Pages 168-178 in The Evaluation of Feeds Through Digestibility Experiments. University of Georgia Press, Athens.

Smith, H. W. 1965. Observations on the flora of the alimentary tract of animals and factors affecting its composition. J. Pathol. Bacteriol. 89:95-122.

Tager, L. R., and K. M. Krause. 2011. Effects of essential oils on rumen fermentation, milk production, and feeding behavior in lactating dairy cows. J. Dairy Sci. 94:2455-2464.

Tannock, G. W. 2001. Molecular assessment of intestinal microflora. Am. J. Clin. Nutr. 73(Suppl.):410S-414S.

Tassoul, M. D., and R. D. Shaver. 2009. Effect of a mixture of supplemental dietary plant essential oils on performance of periparturient and early lactation dairy cows. J. Dairy Sci. 92:1734-1740.

Tekippe, J. A., A. N. Hristov, K. S. Heyler, T. W. Cassidy, V. D. Zheljazkov, J. F. S. Ferreira, S. K. Karnati, and G. A. Varga. 2011.
Rumen fermentation and production effects of Origanum vulgare L. in lactating dairy cows. J. Dairy Sci. 94:5065-5079.

Van Soest, P. J., J. B. Robertson, and B. A. Lewis. 1991. Methods for dietary fiber, neutral detergent fiber, and nonstarch polysaccharides in relation to animal nutrition. J. Dairy Sci. 74:3583-3597.

Wallace, R. J. 2004. Antimicrobial properties of plant secondary metabolites. Proc. Nutr. Soc. 63:621-629.

Wang, J. P., J. S. Yoo, H. D. Jang, J. H. Lee, J. H. Cho, and I. H. Kim. 2011. Effect of dietary fermented garlic by Weissella koreensis powder on growth performance, blood characteristics, and immune response of growing pigs challenged with Escherichia coli lipopolysaccharide. J. Anim. Sci. 89:2123-2131.

Wang, R. J., D. F. Li, and S. Bourne. 1998. Can 2000 years of herbal medicine history help us solve problems on the year 2000? Pages 273-291 in Biotechnology in the Feed Industry. Proc. Alltech's 14th Annual Symposium. University Press, Nottingham, UK.

Watanabe, T., T. Kawada, M. Kurosawa, A. Sato, and K. Iwai. 1988. Adrenal sympathetic efferent nerve and catecholamine secretion excitation caused by capsaicin in rats. Am. J. Physiol. 255:E23E27.

Watanabe, T., T. Kawada, M. Yamamoto, and K. Iwai. 1987. Capsaicin, a pungent principle of hot red pepper, evokes catecholamine secretion from the adrenal medulla of anesthetized rats. Biochem. Biophys. Res. Commun. 142:259-264.

Waters, W. R., T. E. Rahner, M. V. Palmer, D. Cheng, B. J. Nonnecke, and D. L. Whipple. 2003. Expression of L-selectin (CD62L), $\mathrm{CD} 44$, and $\mathrm{CD} 25$ on activated bovine $\mathrm{T}$ cells. Infect. Immun $71: 317-326$.

Weiss, D. J., and K. J. Wardrop. 2010. Page 308 in Schalm's Veterinary Hematology. 6th ed. Blackwell Publishing, Ames, IA.

White, H. M., S. L. Koser, and S. S. Donkin. 2011. Characterization of bovine pyruvate carboxylase promoter 1 responsiveness to serum from control and feed-restricted cows. J. Anim. Sci. 89:1763-1768.

Yang, W. Z., C. Benchaar, B. N. Ametaj, A. V. Chaves, M. L. He, and T. A. McAllister. 2007. Effects of garlic and juniper berry essential oils on ruminal fermentation and on the site and extent of digestion in lactating cows. J. Dairy Sci. 90:5671-5681.

Yasni, S., K. Yoshiie, H. Oda, M. Sugano, and K. Imaizumi. 1993. Dietary Curcuma xanthorrhiza Roxb. increases mitogenic responses of splenic lymphocytes in rats, and alters populations of the lymphocytes in mice. J. Nutr. Sci. Vitaminol. (Tokyo) 39:345-354.

Youn, H. J., J. Larkitz, G. E. Rottinghaus, H. S. Seo, D. Y. Kim, M. H. Cho, and A. E. Marsh. 2004. Anti-protozoal efficacy of high performance liquid chromatography fractions of Torilis japonica and Sophora flavescens extracts on Neospora caninum and Toxoplasma gondii. Vet. Parasitol. 125:409-414.

Youn, H. J., and J. W. Noh. 2001. Screening of the anticoccidial effects of herb extracts against Eimeria tenella. Vet. Parasitol. $96: 257-263$. 